JBT 00194

\title{
Cloning and phenotypic expression in Escherichia coli of a Bacillus subtilis gene fragment coding for sucrose hydrolysis
}

\author{
K. Friehs, K. Schörgendorfer, H. Schwab * and R.M. Lafferty \\ Institut für Biotechnologie, Mikrobiologie und Abfalltechnologie, Technische Universität Graz, \\ Schlögelgasse 9, A-8010 Graz, Austria
}

(Received 22 August, 1985; accepted 14 December 1985)

\section{Summary}

A DNA fragment from Bacillus subtilis strain Marburg coding for the synthesis of an enzyme catalyzing sucrose hydrolysis was cloned in Escherichia coli and detected using simple direct selection of transformants growing on sucrose. Three different clones were obtained each having a $2.5 \mathrm{~kb} E c o$ RI-Pst I fragment in common which was shown to be sufficient to mediate growth on sucrose. This fragment was not identical with known cloned gene fragments of $B$. subtilis coding for the sucrose hydrolyzing enzymes sucrase and levansucrase. It could be shown that the $2.5 \mathrm{~kb}$ fragment codes for a third sucrose hydrolyzing enzyme, namely for levanase. In the case of $E$. coli this enzyme was found to be mainly intracellular; however, a small quantity was also excreted into the periplasmic space.

recombinant DNA, sucrose hydrolysis, inulin, levanase, Bacillus subtilis, Escherichia coli

\section{Introduction}

The use of carbohydrates as renewable sources for the production of chemicals, food and energy is subject to increasing interest (Dunnill, 1981; Righelato, 1980). Thus enzymes involved in carbohydrate metabolism are of great importance both

\footnotetext{
* To whom correspondence should be sent.
} 
for the biotechnological and food industries. The production of such enzymes is one particular reason to clone genes coding for those specific proteins. Another particular aspect is to have available those genes for the purposes of strain improvement using recombinant DNA techniques with microorganisms already employed in bioprocesses (Schwab, 1981).

The genus Bacillus is a source of many different hydrolytic enzymes which are mostly excreted from the cell (Priest, 1977). In the case of Bacillus subtilis, three enzymes capable of hydrolyzing sucrose have been described (Lepesant et al., 1972; Lepesant et al., 1974; Kunst et al., 1977). The corresponding genes for two of these enzymes have been recently cloned in $E$. coli. However, phenotypic expression in $E$. coli could not be detected either for sucrase (Fouet et al., 1982) or for levansucrase (Gay et al., 1983). On the other hand, intracellular production of both of these enzymes in $E$. coli has been reported by the authors cited above.

The results presented here pertain to the cloning and characterization of a third, different gene from $B$. subtilis which codes for sucrose hydrolysis and, furthermore, enables strains of $E$. coli containing this fragment to grow on sucrose as the sole carbon source.

\section{Materials and Methods}

\section{Bacterial strains, cloning vectors, media and culture conditions}

Bacillus subtilis strain Marburg was obtained from the "Deutsche Sammlung von

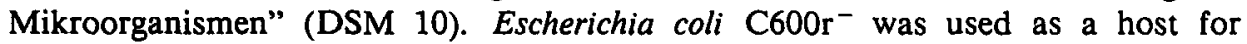
recombinant plasmids and was obtained from W. Wenzel, Cold Spring Harbour Laboratories. The $E$. coli strain DS410 producing minicells was a gift from A. Pühler, University of Bielefeld, F.R.G. The vector plasmid pBR322 (Bolivar et al., 1977) was provided by P. Starlinger, University of Cologne, F.R.G.

Bacterial cells were routinely grown at 30 or $37^{\circ} \mathrm{C}$ in nutrient broth $\left(8 \mathrm{~g} \mathrm{l}^{-1}\right.$, Difco instant preparation) or in LB medium $\left(10 \mathrm{~g}^{-1}\right.$ bacto tryptone, $5 \mathrm{~g}^{-1}$ bacto yeast extract, $5 \mathrm{~g} \mathrm{l}^{-1} \mathrm{NaCl}$ ). For the selection of plasmids the antibiotics tetracycline $\left(15 \mathrm{mg} \mathrm{l}^{-1}\right)$ or ampicillin $\left(100 \mathrm{mg}^{-1}\right)$ were added as required. To select for growth on sucrose a M9 mineral salts medium (Miller, 1972) supplemented with essential amino acids $\left(20 \mathrm{mg} \mathrm{l}^{-1}\right)$ and with thiamine $\left(1 \mathrm{mg} \mathrm{l}^{-1}\right)$ and also containing sucrose $\left(2 \mathrm{~g} \mathrm{l}^{-1}\right)$ as the sole carbon source was used. Sucrose containing no other monosaccharides (Sigma) was separately sterilized by filtration $(0.2 \mu \mathrm{m}$ membrane filters) to avoid hydrolysis by heat sterilization. Media were usually solidified by the addition of $1.5 \%$ agar.

\section{Cloning procedures and restriction analysis}

Chromosomal DNA from B. subtilis was extracted according to the method of Saito and Miura (1963). Minipreparations of plasmid DNA from E. coli strains for rapid analysis of clones were obtained by the alkaline lysis method of Birnboim and Doly (1979) with slight modifications. Preparation of purified plasmid DNA used for cloning purposes and for detailed restriction analysis was done by $\mathrm{CsCl}$ /ethidium 
bromide (EtBr) gradient centrifugation of cell lysates prepared by alkaline lysis of cells as described in Maniatis et al. (1982). After removal of EtBr by extraction with water-saturated $n$-butanol the DNA was dialyzed against TE buffer ( $10 \mathrm{mM}$ Tris, 1 mM EDTA, pH 8.0) and concentrated by ethanol precipitation. DNA preparations were stored in TE buffer at $4^{\circ} \mathrm{C}$ or at $-20^{\circ} \mathrm{C}$.

All cloning procedures were performed according to standard methods as described in Maniatis et al. (1982). Restriction endonucleases and DNA modifying enzymes were purchased either from BRL (F.R.G.) or from Boehringer Mannheim (F.R.G.) and used under conditions as recommended by the suppliers. Agarose gels were usually run in the sub-cell mode. For the separation of small DNA fragments vertical polyacrylamide slab gels were used. In each case a Tris-borate buffer ( 89 mM Tris, $89 \mathrm{mM}$ boric acid, $2.5 \mathrm{mM}$ EDTA, pH 8.0) was used. Elution of DNA fragments from agarose gels was performed by the freeze-squeeze method as described by Thuring et al. (1975).

\section{Determination of enzyme activities}

For the determination of inulin degrading activities according to Kunst et al. (1977), cells were cultured in $300 \mathrm{ml}$ sucrose mineral salts medium for $48 \mathrm{~h}$ at $30^{\circ} \mathrm{C}$. The cells were harvested by centrifugation, washed with $0.9 \% \mathrm{NaCl}$ and finally suspended in $10 \mathrm{ml}$ citrate buffer $(0.32 \mathrm{M}, \mathrm{pH} 4.6)$. The cells were then disrupted with a French press $\left(800 \mathrm{lb} / \mathrm{in}^{2}, 0^{\circ} \mathrm{C}\right) .1 \mathrm{ml}$ of the cell lysate was mixed with $1 \mathrm{ml}$ of reaction buffer $\left(0.2 \mathrm{M} \mathrm{Na}_{2} \mathrm{HPO}_{4}, 0.2 \mathrm{M}\right.$ sodium acetate, $10 \mathrm{mM}$ inulin, $\left.\mathrm{pH} 5.0\right)$ and incubated at $37^{\circ} \mathrm{C}$. Samples of $0.1 \mathrm{ml}$ were taken at regular intervals and heated for $5 \mathrm{~min}$ at $95^{\circ} \mathrm{C}$ to inactivate all enzymes. After centrifugation to remove all cellular particles, the fructose content in the supernatant was determined enzymatically (Boehringer Mannheim, F.R.G.).

Saccharolytic enzyme activities with respect to their intracellular, periplasmic or extracellular location in $E$. coli cells were determined as follows: Cells from a 48-h culture on sucrose mineral salts medium $(50 \mathrm{ml})$ were harvested by centrifugation; the supernatant was designated the extracellular fraction (fraction a). Cells from the same culture were washed with $0.9 \% \mathrm{NaCl}$, suspended in $5 \mathrm{ml}$ citrate buffer $(0.32 \mathrm{M}$, $\mathrm{pH}$ 4.6) and disrupted with a French press as described. This French press lysate represents the total of intracellular and periplasmic enzymatic activities (fraction b). Fractions solely representing periplasmic enzymatic activity were prepared according to the method described by Cornelis et al. (1982). With this procedure enzymes are released from the cells by gentle osmotic shock treatment (fraction c).

All of these fractions were examined for their ability to catalyse sucrose hydrolysis. Experimentally a buffered sucrose solution $(0.5 \%$ sucrose in $0.32 \mathrm{M}$ citrate buffer, $\mathrm{pH}$ 4.6) was added to each fraction in ratios of $1: 1$ to $1: 10$ and the mixtures were then incubated at $37^{\circ} \mathrm{C}$. Samples were removed at regular time intervals, heated to $95^{\circ} \mathrm{C}$ for $5 \mathrm{~min}$ and clarified by centrifugation. The glucose content of the supernatant was determined enzymatically using a commercial test combination (Boehringer Mannheim, F.R.G.).

Analysis of gene products with minicells

Purified DNA from plasmids to be analysed was transformed into the minicell 
producing strain $E$. coli DS410. Plasmid DNA from the proper phenotypical transformants was subjected to restriction analysis in order to check for the correct plasmid genotype. Cells of the analysed transformants were grown in $250 \mathrm{ml} \mathrm{LB}$ medium containing tetracycline $\left(10 \mathrm{mg} \mathrm{l}^{-1}\right)$ to an optical density of $4-5(420 \mathrm{~nm}$, $d=1.0 \mathrm{~cm})$. Viable cells were removed by low speed centrifugation $(600 \times g, 10$ $\mathrm{min}$ ). The supernatant containing the minicells was then centrifuged at $10000 \times \mathrm{g}$ for $15 \mathrm{~min}$ to harvest the remaining cells. Minicells were then purified by four sequential centrifugations through 10-30\% sucrose gradients as described by ClarkCurtiss and Curtiss (1983). Labeling of proteins produced by the minicells was performed with $\left[{ }^{35} \mathrm{~S}\right]$ methionine according to Meagher et al. (1977). After lysis by SDS, the proteins were separated on vertical polyacrylamide-SDS gels and subsequently detected by autoradiography using X-ray film (Kodak type S3).

\section{Results}

Cloning of Bacillus subtilis DNA fragments coding for sucrose hydrolysis

Chromosomal DNA of $B$. subtilis strain Marburg was partially digested with the restriction endonucleases EcoRI and Pst $\mathrm{I}$. Conditions for cleavage resulting in a maximum of fragments within a size range of $2-5 \mathrm{~kb}$ were determined in preceding experiments by variation of enzyme concentration and duration of incubation. Finally, $10 \mu \mathrm{g}$ of $B$. subtilis DNA were simultaneously digested with $5 \mathrm{U} E c o$ RI and $5 \mathrm{U}$ Pst $\mathrm{I}$ in a $100 \mu \mathrm{l}$ reaction mixture for $60 \mathrm{~min}$ at $37^{\circ} \mathrm{C}$.

DNA of the plasmid pBR322 purified by density gradient centrifugation was digested with the same enzymes and the resulting fragments were separated on a $0.7 \%$ agarose gel. The large $3.6 \mathrm{~kb}$ fragment of pBR322 was eluted from the gel by the freeze-squeeze method (Thuring et al., 1975). B. subtilis DNA fragments generated by partial EcoRI and Pst I digestion were ligated to the large EcoRI-Pst I fragment of pBR322 using T4 DNA ligase and transformed into E. coli C600r ${ }^{-}$. Tetracycline-resistant, ampicillin-sensitive transformants were selected and subsequently screened on M9-sucrose agar plates. From more than 1000 clones tested, three clones were isolated that were capable of growing on sucrose. Although the growth of these clones on sucrose mineral medium was much slower than on glucose media, colonies growing on sucrose media could be clearly identified after 2 days incubation. In the case of these three isolated clones no significant difference could be detected with respect to growth behaviour.

\section{Restriction analysis of hybrid plasmids}

Plasmid DNA was isolated from each of the three sucrose-positive $E$. coli clones and analysed with the restriction enzymes EcoRI and Pst I. It was found that all hybrids contain a $2.5 \mathrm{~kb}$ fragment in addition to the $3.6 \mathrm{~kb}$ vector fragment. The plasmid pKF3 consists solely of the $3.6 \mathrm{~kb}$ vector fragment and the $2.5 \mathrm{~kb} \mathrm{~B}$. subtilis DNA fragment. In contrast to the other two hybrids pKF1 and pKF2 it does not contain additional DNA (Fig. 1). Therefore, it is highly probable that this $2.5 \mathrm{~kb}$ fragment contains the genetic information for sucrose hydrolysis. In order to 

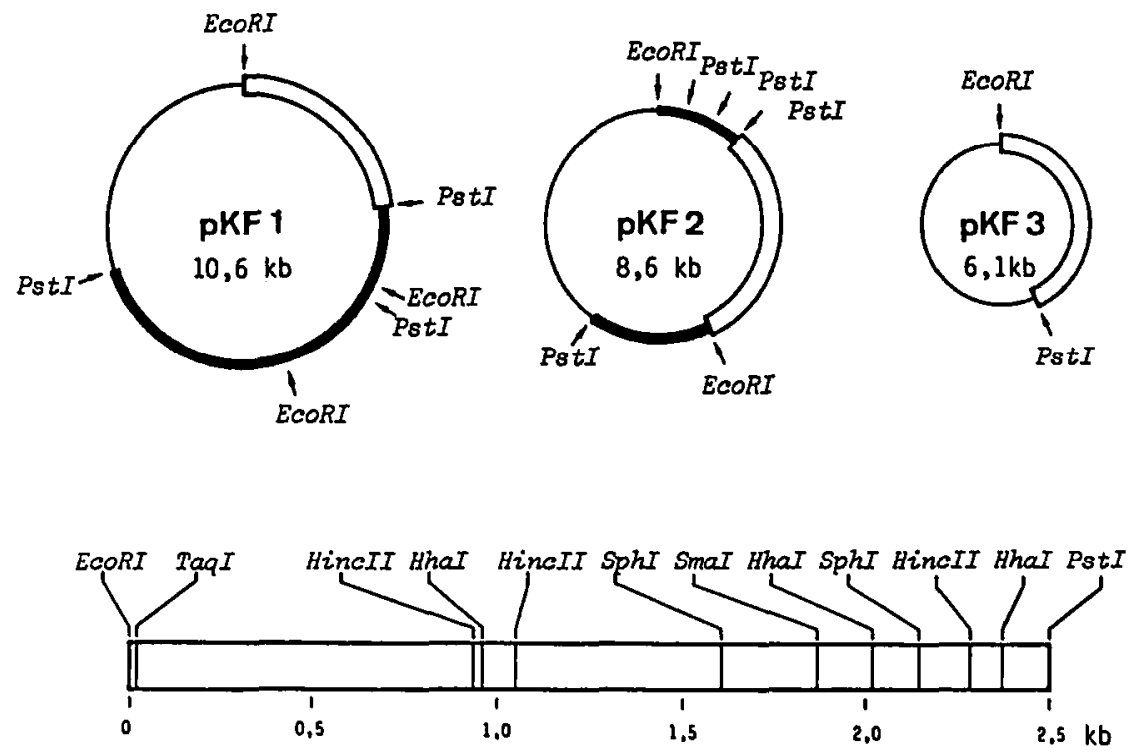

Fig. 1. Restriction maps of the recombinant plasmids mediating sucrose hydrolysis. The fine line represents the vector part (EcoRI/Pst I fragment of pBR322). The heavy line represents $B$. subtilis DNA not essential for sucrose hydrolysis. The double lined segment represents the $2.5 \mathrm{~kb} E c o R I / P_{s t} \mathrm{I} B$. subtilis DNA fragment common to all three plasmids and encoding sucrose hydrolysis. A more detailed map of this fragment is shown in the lower part of the drawing.

investigate this fact, the $2.5 \mathrm{~kb}$ fragments from pKF1 and pKF2 were subcloned into the $3.6 \mathrm{~kb} E c o \mathrm{RI}-P s t \mathrm{I}$ fragment of pBR322 and transformed into $E$. coli $\mathrm{C}^{6} 00 \mathrm{r}^{-}$. Hybrids containing solely the $2.5 \mathrm{~kb}$ fragment could be isolated from both sources, i.e. from pKF 1 and pKF2 respectively. All such clones tested in more detail ( 8 each) showed growth on sucrose when supplied as the sole carbon source.

By digestion of DNA of the plasmids pKF1, pKF2 and pKF3 with further restriction enzymes, it was possible to physically confirm that the $2.5 \mathrm{~kb}$ fragment is identical in all of the three different clones. It could also be determined that the 2.5 $\mathrm{kb}$ fragments are located in different orientations with respect to the vector parts in the plasmids pKF1 and pKF3 in comparison to pKF2 (Fig. 1).

The $2.5 \mathrm{~kb}$ fragment was further analysed in more detail by means of restriction enzyme digestions of the plasmid pKF3 and of purified DNA of the $2.5 \mathrm{~kb}$ Eco RI-Pst I fragment obtained by freeze-squeeze elution from agarose gels. A map of this fragment is shown in Fig. 1. In addition to the marked positions for restriction sites of several enzymes, it was found that there are no cleavage sites located on the $2.5 \mathrm{~kb}$ fragment for the restriction endonucleases $B a m \mathrm{HI}, B g / \mathrm{II}$, HaeII, HindIII, KpnI, SalI, SstII and XhoI.

Characterization and localization of enzyme activities in $E$. coli

By comparing our results of the restriction enzyme analysis with the published 


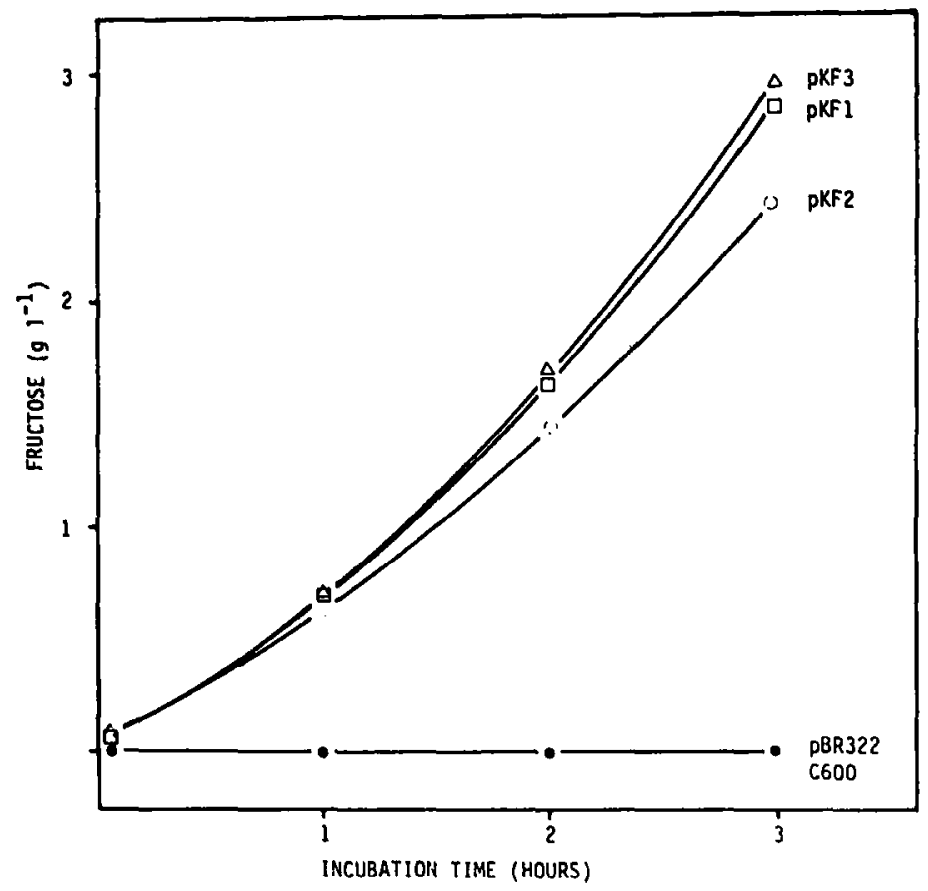

Fig. 2. Inulin degradation abilities of cell lysates of $E$. coli ${\mathrm{C} 600 \mathrm{r}^{-}}^{-}$containing recombinant plasmids as measured by the formation of free fructose from inulin. The respective plasmids are marked at the right end of the corresponding curves. The plasmid-free host strain, marked as "C600", and the strain containing the vector plasmid pBR322 without any $B$. subtilis DNA insert were also analyzed for comparison.

data pertaining to cloned gene fragments of $B$. subtilis containing the sucrase (Fouet et al., 1982) and the levansucrase gene respectively (Gay et al., 1983), we found that there are no existing common features between these fragments and the $2.5 \mathrm{~kb}$ fragment. Therefore, it was obvious to look for indications of the third possible sucrose hydrolyzing enzyme in B. subtilis, namely levanase (Kunst et al., 1977). Levanase is the only one of the three enzymes which is capable of hydrolyzing the fructosan inulin, a molecule consisting of approximately $30 \beta-1,2$-connected fructose units with a sucrose molecule at one end.

Whole cell lysates from $E$. coli clones harbouring plasmids pKF1, pKF2 or pKF3 were tested for inulin hydrolyzing activities as described in Materials and Methods. As can be seen from Fig. 2, all lysates prepared from the three different clones show nearly identical inulin degrading activities. Therefore, it may be concluded that the $2.5 \mathrm{~kb}$ fragment carries the genetic information for the enzyme levanase.

No growth of $E$. coli strains containing either the cloned sucrase gene or the cloned levansucrase gene (Fouet et al., 1982; Gay et al., 1983) could be detected even though the corresponding enzymes were produced intracellularly. Thus it was very interesting to determine just where the levanase activity is located in $E$. coli. 
Extracellular, periplasmic and intracellular enzyme activities were therefore determined. It was found that no extracellular sucrose hydrolyzing activity is present in culture fluids (fraction a) following growth of $E$. coli strains harbouring pKF1, pKF2 or pKF3 plasmids. However, a low activity could be detected in fractions representing periplasmic enzymes (fraction c). But in comparison to fractions b which represent intracellular plus periplasmic activities, and where the major activity could be found, the periplasmic activity represents only about $0.2-1 \%$ of the total activity. On the basis of these data we suggest that the levanase is at least to a small extent transported into the periplasmic space of $E$. coli cells thus resulting in the ability to grow on sucrose media.

\section{Identification of plasmid encoded proteins in minicells}

A series of minicell experiments were performed with pKF plasmids in order to detect proteins responsible for sucrose hydrolysis and much effort was put into minicell purification. The quality of the minicell preparations was found to be quite satisfactory with respect to vector encoded proteins, however, no visible protein bands specific for the $2.5 \mathrm{~kb}$ fragment could be detected.

Since the synthesis of proteins is limited by the amount of RNA polymerase present in minicells, strong promoters bind most of the available RNA polymerase resulting in a very low expression of genes transcribed from weak promoters (Crooks et al., 1983). Therefore, as an explanation for the fact that proteins encoded by the $2.5 \mathrm{~kb}$ fragment could not be clearly detected, we assume that such proteins are transcribed in $E$. coli from very weak promoters possibly being those from $B$. subtilis.

\section{Discussion}

A $2.5 \mathrm{~kb}$ EcoRI-PstI fragment of the chromosomal DNA of Bacillus subtilis strain Marburg, cloned into the $3.6 \mathrm{~kb}$ EcoRI-Pst I fragment of pBR322, was shown to code for sucrose hydrolyzing activity. In contrast to recently described cloned $B$. subtilis DNA fragments coding for the enzymes sucrase (Fouet et al., 1982) and levansucrase (Gay et al., 1983), this fragment enables cells of $E$. coli to grow on sucrose as the sole carbon source. Since the identical $2.5 \mathrm{~kb}$ fragment was found to be present in three different hybrid plasmids it is suggested that this fragment codes for a specific sucrose hydrolyzing enzyme.

No significant difference with respect to the growth behaviour on sucrose between the $E$. coli clones containing the different plasmids pKF1, pKF2 or pKF3 could be found. The plasmid $\mathrm{pKF} 3$ contains only the $2: 5 \mathrm{~kb} B$. subtilis DNA fragment whereas pKF1 and pKF2 contain this fragment and additional $B$. subtilis DNA. Furthermore, the $2.5 \mathrm{~kb}$ fragment is located in a different orientation in one of the hybrids compared to the other two (Fig. 1). Thus these facts might be good evidence that expression of the sucrose hydrolyzing enzyme in $E$. coli will be controlled by a $B$. subtilis promoter located within the $2.5 \mathrm{~kb}$ fragment. In addition, E. coli $\mathrm{C} 600$ clones containing a hybrid plasmid consisting of the $2.5 \mathrm{~kb} \mathrm{~B}$. subtilis 
DNA fragment cloned into the broad host range vector pMMB33 (Frey, 1983) were found to grow on sucrose with similar characteristics as found with $E$. coli C600 clones containing one of the pKF plasmids (Friehs, unpublished results). An interesting fact was the finding of a sucrose hydrolyzing activity in the periplasmic space of $E$. coli clones harbouring pKF plasmids, although the main enzyme activity was located intracellularly. Nevertheless, this fact may give rise to the supposition that the $B$. subtilis secretion information may at least be poorly expressed in $E$. coli. However, additional data are necessary to allow more precise conclusions.

As could be found by detailed restriction analysis of the $2.5 \mathrm{~kb} \mathrm{~B}$. subtilis DNA fragment, no homology is given with respect to the cloned gene fragments coding for sucrase (Fouet et al., 1982) or levansucrase (Gay et al., 1983). By testing cell lysates of $E$. coli clones harbouring plasmids containing the $2.5 \mathrm{~kb}$ fragment for inulin hydrolyzing activities, much evidence was obtained for the fact that this fragment codes for the enzyme levanase. This enzyme is the only one of the sucrose hydrolyzing enzymes in $B$. subtilis which is able to hydrolyse inulin. However, studies of the growth behaviour of $E$. coli strains harbouring pKF plasmids on mineral salts media containing inulin as the sole carbon source showed that growth on inulin was much slower compared to growth on sucrose. We suggest that sucrose or inulin must be transported across the outer membrane of $E$. coli to the periplasmic space and is then hydrolyzed to monosaccharides which can be taken up into the cell. Apparently such a sequence would cause more difficulties to the utilization of the larger inulin molecule as a carbon source.

In looking for proteins coded for by the $2.5 \mathrm{~kb}$ fragment by analysing newly synthesized proteins produced by minicells harbouring the plasmid pKF3, we were not able to detect protein bands clearly specific for the $2.5 \mathrm{~kb}$ fragment even though a large number of experiments using highly purified minicell preparations were performed.

One suggestion is that the expression of the levanase is controlled by a promoter which shows only a weak activity in $E$. coli and therefore, in minicells the quantity of protein synthesized is too low to be clearly detected. This would support the idea that expression of the sucrose hydrolyzing enzyme (levanase) which is encoded by the $2.5 \mathrm{~kb}$ B. subtilis DNA fragment is controlled by a $B$. subtilis promoter which shows only weak activity in $\mathrm{E}$. coli.

A more detailed analysis of the $2.5 \mathrm{~kb}$ fragment by sequencing should provide better information concerning encoded genes and their expression. Experiments for this purpose have been already started.

\section{Acknowledgements}

This work was supported by the Fonds zur Förderung der Wissenschaftlichen Forschung (Project No. 4529). We are very grateful to $\mathrm{C}$. Hohengasser for helping in the preparation of SDS-polyacrylamide gels. 


\section{References}

Birnboim, H.C. and Doly, J. (1979) A rapid alkaline extraction procedure for screening recombinant plasmid DNA. Nucleic Acids Res. 7, 1513-1523.

Bolivar, F., Rodriguez, R.L., Greene, P.J., Betlach, M.C., Heyneker, H.L., Boyer, H.W., Crosa, J.H. and Falkow, S. (1977) Construction and characterization of new cloning vehicles. II. A multipurpose cloning system. Gene 2, 95-113.

Christen, A.A., Pall, M.L., Manzara, T. and Lurquin, P.F. (1983) Rapid isolation of Escherichia coli minicells by glass-fiber filtration: study of plasmid-coded polypeptides. Gene 23, 195-198.

Clark-Curtiss, J.E. and Curtiss, R., III (1983) Analysis of recombinant DNA using Escherichia coli minicells. Methods Enzymol. 101, 347-371.

Cornelis, P., Digneffe, C. and Willemot, K. (1982) Cloning and expression of a Bacillus coagulans amylase gene in Escherichia coli. Mol. Gen. Genet. 185, 507-511

Crooks, J.H., Ullman, M., Zoller, M. and Levy, S.B. (1983) Transcription of plasmid DNA in Escherichia coli minicells. Plasmid 10, 66-72.

Dunnill, P. (1981) Biotechnology and industry. Chem. Industry 4, 204-217.

Fouet, A., Klier, A. and Rapoport, G. (1982) Cloning and expression in Escherichia coli of the sucrase gene from Bacillus subtilis. Mol. Gen. Genet. 186, 399-404.

Frey, K. (1983) Stable cosmid vectors that enable the introduction of cloned fragments into a wide range of Gram-negative bacteria. Gene 24, 299-308.

Gay, P., Le Coq, D., Ferrari, E., Steinmetz, M. and Hoch, J.A. (1983) Cloning structural gene sacB, which codes for exoenzyme levansucrase of Bacillus subtilis: Expression of the gene in Escherichia coli. J. Bacteriol. 153, 1424-1431.

Kunst, F., Steinmetz, M., Lepesant, J.-A. and Dedonder, R. (1977) Presence of a third sucrose hydrolyzing enzyme in Bacillus subtilis: constitutive levanase synthesis by mutants of Bacillus subtilis Marburg 168. Biochimie 59, 287-292.

Lepesant, J.-A., Kunst, F., Lepesant-Kejzlarova, J. and Dedonder, R. (1972) Chromosomal location of mutations affecting sucrose metabolism in Bacillus subtilis Marburg. Mol. Gen. Genet. 118, 135-160.

Lepesant, J.-A., Lepesant-Kejzlarova, J., Pascal, M., Kunst, F., Billaut, A. and Dedonder, R. (1974) Identification of the structural gene of levansucrase in Bacillus subtilis Marburg. Mol. Gen. Genet. 128, 213-221.

Maniatis, T., Fritsch, E.F. and Sambrook, J. (1982) Molecular cloning. Cold Spring Harbor Laboratory, Cold Spring Harbor, NY.

Meagher, R.B., Tait, R.C., Betlach, M. and Boyer, H.W. (1977) Protein expression in E. coli minicells by recombinant plasmids. Cell 10, 521-536.

Miller, J.H. (1972) Experiments in molecular genetics. Cold Spring Harbor Laboratory, Cold Spring Harbor, NY.

Priest, F.G. (1977) Extracellular enzyme synthesis in the genus Bacillus. Bacteriol. Rev. 41, 711-753.

Righelato, R.C. (1980) Microbial production of energy sources from biomass. Phil. Trans. R. Soc. Lond. A 295, 491-500.

Saito, H. and Miura, K.-I. (1963) Preparation of transforming DNA by phenol treatment. Biochim. Biophys. Acta 72, 619-629.

Sancar, A., Hack, A.M. and Rupp, W.D. (1979) Simple method for identification of plasmid-coded proteins. J. Bacteriol. 137, 692-693.

Schwab, H. (1981) Genetic engineering. In: Fermentation (Lafferty, R.M., ed.), pp. 212-226, SpringerVerlag, Wien-New York.

Thuring, R.W.J., Sanders, J.P.M. and Borst, P. (1975) A freeze-squeeze method for recovering large DNA from agarose gels. Anal. Biochem. 66, 213-220. 